\title{
2013-2014 YILI EDİRNE YENİ SARAY KAZISI İZNİK VE KÜTAHYA SERAMİKLERİ
}

Hasan Uçar ${ }^{1}$

\begin{abstract}
ÖZ
$\mathrm{Bu}$ çalışmanın içeriğini 2013-2014 yıllarında Edirne Yeni Saray'da gerçekleştirilen kazılarda bulunmuş İznik ve Kütahya seramikleri oluşturmaktadır. Saray 15. yüzyıl ilk yarısının sonlarında inşa edilmeye başlamış ve sonrasında Osmanlı padişahlarınca sürekli kullanılmıştır. 18. yüzyıldan itibaren klasik dönemdeki önemini kaybetmeye başlayan saray, Osmanlı-Rus Savaşı ile yıkım sürecine girmiştir. Cumhuriyet Dönemi'nde farklı yıllarda yapılan kazı çalışmaları ile sarayın mimari özellikleri yanında sarayda kullanılan eşyalar da gün yüzüne çıkarılmaya çalışılmaktadır. Bu malzemelerden olan İznik ve Kütahya seramikleri, sarayda kullanılan ithal seramiklerin yanında özel bir konuma sahiptir. Bezeme teknikleri aynı olsa da renkleri ve motifleri farklılık gösteren bu seramikler Osmanlı'nın bir dönemki zevk anlayışını yansıtmaları açısından birer belge niteliği taşımaktadır. Tek renk ve çok renk boyalı İznik seramiklerinde mavi-beyaz seramikler 15. yüzyıl sonu 16. yüzyıl ilk yarısının bezeme anlayışını, çok renk boyalılar ise tamamıyla Osmanlı'nın kendine has bezeme anlayıșını yansıtmaktadır. Kütahya seramiklerinde en dikkat çekici form olan fincanlarda ve az sayıdaki kâse parçasında Kütahya'nın kendine özgü tek ve çok renk boyalı üslubunu görmek mümkündür. 18. yüzyıla tarihlendirilen bu örneklerin kimilerinde Çin etkileri görülürken kimileri tamamıla Kütahyalı seramikçilerin kendi üsluplarını bize gösterir. Bu çalışmada 2013-2014 yıllarında bulunan İznik ve Kütahya seramiklerinin Osmanlı seramikleri içerisindeki yerinin saptanması amaçlanmıştır.
\end{abstract}

Anahtar Kelimeler: İznik, Kütahya, mavi-beyaz, fincan

\section{IZNIK AND KUTAHYA CERAMICS FROM EDİRNE YENİ SARAY EXCAVATION IN 2013-2014}

\begin{abstract}
The content of this work consists of the ceramics of Iznik and Kütahya which were found in excavation carried out in Edirne Yeni Saray in 2013-2014. This palace began to be built at the end of the first half of 15th century and thereafter it was continuously used by

\footnotetext{
1 Dr. Öğr. Üyesi. Ege Üniversitesi, Edebiyat Fakültesi, Sanat Tarihi Bölümü, Bornova-İzmir; hasan.ucar@ege.edu.tr; ORCID ID: 0000-0002-7443-5715; Edirne Yeni Saray Kazısı'nda ortaya çıkarılan seramikleri çalışmama izin veren Prof.Dr. Mustafa ÖZER'e teşekkür ederim.
} 
Ottoman sultans. The palace, which started to lose its significance in classical period from 18th century, entered into the process of demolition by means of Ottoman-Russia war. Besides the architectural features of the palace with the excavation works made in different years in Republic Period, the things used in the palace are also endeavoured to be unearthed. The ceramics of İnik and Kütahya from these materials have a crucial position alongside of imported ceramics which were used in the palace. Even though the adornment techniques are the same, these ceramics of which colours and motifs show difference have the characteristics of a document in terms of reflection of pleasure approach of a period of Ottoman. While the blue-white ceramics show the adornment approach of end of 15th century and first half of 16th century, multi-coloured ones reflect the adornment approach of Ottoman entirely in solid-coloured and multi-coloured Iznik ceramics. It is possible to see single and multi-coloured dyed style of Kütahya in cups which are most notably form and a couple of part of bowl in Kütahya ceramics. While Chinese influence is observed in some of these samples that are dated as 18th century, some of them shows us the style of ceramists from Kütahya entirely. In this work, it is aimed to determine the position of ceramics of İznik and Kütahya which were found in 2013-2014 within Ottoman ceramics.

Keywords: Iznik, Kütahya, blue\&white, cup

\section{Giriş}

Tarih öncesi ve sonrasında toplumların günlük yaşamları hakkında bilgi edindiğimiz objeler arasında yer alan seramikler, o toplumların teknik düzeylerini, önceki ya da çağdaşı çevre kültürlerle etkileşimlerini ve ticari faaliyetleri hakkında bize bilgi veren önemli malzemelerdendir. Edirne Yeni Saray'da bulunan seramikler de bu özellikleri yansıtmaktadır. Yüzyıllarca Bizans hâkimiyetinde kalan toprakların Türk akınlarıyla birlikte kimliği değişmeye başlamış, bu değişiklik kaçınılmaz olarak kültürel ve sanatsal faaliyetlerde kimi zaman yavaş kimi zaman hızlı biçimde değişikliklere sebep olmuştur. $\mathrm{Bu}$ geçiş süreci Türk-İslam-Bizans etkileşiminin en güçlü olduğu dönemlerden biri olarak da gösterilebilir. Türklerin yanlarında getirdikleri günlük kullanım eşyaları, yeme ve içmede kullanılan malzemelerin tercihinde de değişikliğe sebep olmuștur. Yeşil sırlı seramiklerin kimliği çoğu zaman ayırt edilemese de, Milet tipi olarak adlandırılan seramikler Selçuklu geleneğinde sıraltı boyamanın Anadolu'nun en batısında üretilmesi açısından önemlidir. Anadolu birden fazla Türk Beyliğinin kontrolüne geçmişken, 14. yüzyılda 
İstanbul haricinde Rumeli Osmanlıların egemenliğine girmiştir. Osmanlı kontrolü altındaki yerleşimlerdeki imar faaliyetleri bu yerleşimlerin fiziksel görünüşlerinde değişikliklere neden olmuştur. Aynı değişim kullanım eşyaları arasında da görülmektedir. Milet İşi olarak adlandırılan sıraltı boyamalı seramikler bu değişimin Edirne'deki küçük boyutlu objeleri arasında gösterilebilir (1).

1361 yllında Edirne'nin ele geçirilmesi ve payitahtın Bursa'dan Edirne'ye taşınması ile bu kent hem yönetim hem ticaret hem de sanat merkezi olmuștur. İstanbul'un fethinden önce yapımına başlanan ve payitahtın İstanbul'a taşınmasından sonra da yapılaşması devam eden Yeni Saray, yaklaşık 18. yüzyıl ikinci yarısına kadar hanedanlık tarafından sıklıkla kullanılan bir yapı topluluğu olmuştur. Oldukça geniş bir alana kurulmuş saray, Osmanlı-Rus Savaşı sırasında büyük zarar görmüş ve kullanılamaz duruma gelmiștir (2).

Cumhuriyet Dönemi'nde saraya ait kalıntıların ortaya çıkarılmasına yönelik arkeolojik kazılar yapılmıştır. Bazen kısa bazen uzun dönemleri kapsayan bu kazılarda saptanan mimari veriler Osmanlı sarayının plan özellikleri, malzeme ve inşa teknikleri hakkında bilgi verirken, küçük buluntular ise Osmanlı sarayının günlük yaşamından izler aktaran somut varlıklar olması bakımından oldukça önemlidir. Cihannüma Kasrı, Kum Kasrı, Kum Kasrı Hamamı, Matbah-ı Amire gibi yapıların bulunduğu alanlarda yapılan kazı çalışmalarında Osmanlının tüm dönemlerine ait seramikler bulunmuştur (3). Bu seramikler yerli ve ithal seramikler olarak iki ana grup içerisinde toplanmıştır. Yerli seramikler arasında çok olmamakla birlikte Milet tipi seramikler, İznik mavi beyaz ve çok renkli seramikleri, tek renk sırlı ve sırsız seramikler; ithal seramikler içerisinde ise Çin, Avrupa ve Rus seramikleri yer almaktadır. Yaklaşık olarak 400 yıl kullanılan sarayda bulunan seramiklerin dağılımı kuşkusuz farklılık göstermektedir. Bu seramikler içerisinde yer alan ve çalışmanın içeriğini oluşturan İznik ve Kütahya seramikleri kendilerine has üsluplarıyla yerli seramikler arasında kolayca ayırt edilebilmektedir. 2013-2014 yılı çalışmalarında bulunmuş İznik ve Kütahya seramikleri malzeme ve biçim açısından daha önceki dönemlerde saray kazılarında bulunmuş örnekler paralelinde olsalar da, motif ve kompozisyonlarındaki farklılıklarla çeşitlilik oluşturmaktadır. 
İznik Seramikleri (Tablo I, II, III:18-20)

Hem kırmızı hem de beyaz hamurlu seramiklerin üretildiği İznik'te kırmızı hamurlu seramikler kazıma, astar boyama ve sıraltı boyamalı olmak üzere üç farklı teknikle bezenmişlerdir (Altun, 1991: 9-10). 15. yüzyıl sonlarından itibaren yavaş yavaş terkedilen kırmızı hamurun yerini beyaz hamur almış ve çoğunlukla şeffaf sıraltında tek ya da çok renk boyamalı seramikler üretilmiştir (Bilgi, 2009: 15). İznikli ustalar özellikle Kanuni Sultan Süleyman Dönemi'nde yaratıcılıklarıyla en gösterişli ürünleri yapmıştır. Bu ürünler teknik ve bezeme açısından sadece yapıldıkları dönemin değil, sonraki dönemlerin sanatını da etkilemiştir (Atıl, 1987: 235).

2013-2014 yllı Edirne Yeni Saray Kazısı seramikleri içerisinde yer alan İznik seramikleri tüm değildir. Bu parçaların biçimleri dikkate alındığında tabak, sürahi ve kapak gibi türlere ait oldukları anlaşılmaktadır. Mavi beyaz seramiklerden bazı tabak parçaları halka kaidelidir (I:1) Birkaç adet ağız parçasından bunların geniş kenarlı tabaklara ait olabilecekleri anlaşılır $(I: 3,6)$. Ağızları mevcut parçaların tümü basit yuvarlak ağızlıdır. Çok renk boyalı, yuvarlak ağız kenarlı parçanın da bir tabağa ait olduğu benzer örneklerinden kolayca ayırt edilebilmektedir (II:12). Çok renk boyalı buluntular arasında yer alan basit yuvarlak ağız kenarlı bir adet boyun parçası da silindirik boyunlu bir sürahiye ait olmalıdır (II:11). Mavi-beyaz buluntular arasında yer alan iki adet kapak parçası gövde biçimi açısından birbirleriyle benzerdir (I:4;II:7). Yarı küresel gövdeli bu parçalardan sadece bir adedinin tutamağı kısmen sağlam ulaşabilmiştir. Çok renk boyalı diğer parçaların gövde ve kaide biçimleri anlaşılmasa da bu parçaların bazılarının yuvarlak ağızla sonlandığı görülebilmektedir.

Bezeme: 2013-2014 yılı Yeni Saray Kazısı 2013-2014 yılı İznik seramikleri bezeme özelliklerine göre sıraltı tek ve çok renk boyalı seramikler olarak iki gruba ayrılabilir. Sıraltı tek ya da çok renk boyalı seramiklerde kompozisyonun biçimi seramiğin formuna ve dönemine göre değişiklik göstermektedir. Tabak parçalarında (dip hariç) bezeme, seramiklerin hem içyüzünde hem de dış yüzünde dikkati çekerken kapaklarda ve bardaklarda sadece diş yüzde bezeme bulunmaktadır. Dolayısıyla seramiğin açı/kapalı formlu veya sığ/derin oluşu bezeme yapılacak yüzeyin seçimini etkilemiştir.

İznik seramiklerinde bezeme negatif ve pozitif olmak üzere iki yöntemle oluşturulmuştur: Birinci yöntemde yani negatif 
yöntemde bezeme, motiflerin zemin renginde (beyaz) bırakılması, motiflerin etrafının kobalt mavi ile boyanması ile meydana getirilmiștir. $\mathrm{Bu}$ yöntemde beyaz bırakılan motiflerin detayları yine kobalt mavi ile belirginleştirilmiştir $(I: 1,2,6)$. İkinci yöntem, yani pozitif yöntem ise birinci uygulamanın tam tersidir. Beyaz zemin üzerinde motifler renkli boyalarla işlenmiş motiflerin dışı ise boş (zemin renginde) birakılmıştır $(I: 4 ; I I ; 7,12,13)$. Saray seramikleri içerisindeki bazı mavi beyaz seramiklerin her iki yöntemle bezendikleri anlașılmaktadır. Baba Nakkaș üslubu (4) özelliği gösteren tabak parçalarında iç yüzde merkezde ve dışa çekik kenarda birinci yöntem, diş yüzde ise ikinci yöntemle boyama tercih edilmiştir. Çok renk boyalı parçalarda ise genel olarak ikinci yöntem karşımıza çıkmakla birlikte bazı örneklerde motiflerin etrafı yine kobalt mavi ile boyanmıştır (III:18-19). Bu seramiklerde Baba Nakkaş üslubundan farklı olarak gerek çok renkli boyamadan gerekse motiflerde kontur renginin de etrafındaki renklerden farklılık göstermesi, Baba nakkaş üslubundaki negatif etkiyi tam olarak yansitmamaktadır.

Ham madesi nereden geldiği tartışmalı olmakla birlikte İran'ın Kaşan şehrinden geldiği varsayılan ve en önemli renklendirici malzeme olan kobalt mavi, tek renk boyalı (mavi-beyaz) seramiklerin bezenmesinde kullanılmıştır. Bu renk motif ve dolgu rengi olmanın yanında mavi beyazlarda kontur rengi olarak da tercih edilmiștir. Kontur rengi olan kobalt mavi, dolgu rengine göre daha yoğunlaştırılmış bir renktir. (Raby, 1989a: 57,58.) Bu özellik de Edirne sarayı buluntularında görülmektedir. Çok renk boyalı örneklerde ise kontur rengi genellikle siyah, dolgu rengi ise yeşil ve mercan kırmızısıdır. Edirne Yeni Saray Kazısı 2013-2014 yıllarında bulunan İznik seramikleri günümüze tüm ulaşamadığı için kompozisyon kurguları da tam anlaşılamamaktadır. Bazı seramiklerde üç bölümlü kompozisyon düzeni kısmen seçilebilmektedir. Gerek mavi beyaz seramiklerde gerekse çok renk boyalı seramiklerde bitkisel bezemeler daha yoğundur. Kapların formları ve renk şeması açısından Çin mavi beyazlarıyla benzerlik gösterse de bezemeleri açısından Osmanlının kendine has üslubunun görüldüğü Baba Nakkaş üslubundaki (Raby, 1989b: 77-79) Edirne Sarayı mavi beyazlarında bitkisel süslemenin en dikkat çekici motifleri arasında kıvrımlı sarmal dallar üzerindeki motifler gösterilebilir. Çoğunlukla hatayi ve penç motiflerinin yer aldığı bu düzenlemelerde, motiflerin arasında kalan boşluklar da çeşitli yaprak motifleriyle bezenmiştir $(1: 1,2,4,6)$. Rumi motifleri ise bir parçada 
daha belirgin olarak çark-1 felek düzeninde verilmiştir (I:3). Geometrik motifler bitkisel bezemeler içerisinde kolayca ayırt edilebilmektedir. Hem mavi beyazlarda hem de çok renkli seramiklerdeki ortak geometrik motif düz çizgilerdir. Bitkisel bezeme içerisinde biçimleriyle dikkat çekici bir motif olmasa da bitkisel motifleri sınırlandırmaktadır. Çoklukla ikili olarak kullanılan çizgiler tabakların zeminini belirginleştirirken (I:1) dişa çekik kenarlarda ve kapaklarda birer bordür oluşturmaktadır (I:2,4,6;II:7). Ağız biçimleri anlaşılabilen örneklerde tabak ağız kenarı yuvarlak ise bordür çizgileri de düzdür. Dolayısıyla ağız kenarı formu ile çizgiler oldukça uyumludur. İki adet kenar parçasının dış yüzünde ikili çizgilerle bordür oluşturulmuş ve bu bordürlerin içerisi dilimli çizgilerle bezenmiştir $(I: 2,6)$. Bir örnekte de bu dilimli çizgilerin sivri noktaları aynı tipte stilize çiçek motifleriyle süslenmiştir. İkili düz çizgiler çoğunlukla sade bırakılırken bir adet tabak parçasında dıştaki çizgi stilize yaprak motifleriyle hareketlendirilmiş̦tir (I:1). Ayrıca, mavi beyaz kapaklarda ikili çizgilerle oluşturulmuş dar bordürlerde çeşitli geometrik motifler görülmektedir. Çok renk boyalı seramiklerdeki çizgiler renk bakımından farklı olmakla birlikte mavi beyazlara göre daha özensiz oldukları seçilebilmektedir. Bu durumu belirginleştiren en önemli özellik renk farklılı̆̆ıdır. Mavi beyaz seramiklerde çizgi rengi daha koyu olsa da çevrelediği motiflerin de mavi oluşu çizgilerdeki ton ve kalınlık farklılıklarının seçilmesini engellemektedir. Çok renk boyalılarda ise siyah rengin daha baskın oluşundan dolayı etrafındaki renklerden kolayca ayırt edilmektedir. $\mathrm{Bu}$ da çizgilerdeki kalınlık ve ton farklılıklarının saptanmasını kolaylaştırmaktadır. Ayrıca mavi beyazlarda ikili olan çizgiler çok renklilerde teklidir ve bu çizgiler ortak bordür çizgisi olarak kullanılmıştır (II:11,12,17; III:20).

15. yüzyıl ikinci yarısından sonra mavi beyaz üslubun gerek saray, gerekse seramikçiler tarafından benimsenmesi, Selçuklu geleneğindeki üretimi zayıflatmış ve 16. yüzyıl ikinci yarısına kadar da mavi beyaz üslupta seramikler üretilmiștir. Yüzyılın ikinci çeyreğiyle birlikte firuze ve yeşil renklerle birlikte kobalt mavinin kompozisyondaki baskınlığı kırılmıştır. Nakkaşhanede çalışan kişilere bağlı olarak yüzyıl ikinci yarısından itibaren de renk dağılımlarının tercih edilen motiflere göre değiștiği çok renk boyalı seramikler üretilmeye başlanmıştır (Özkul Fındık, 2001: 220-226; Turan Bakır, 2007: 289-302). Bu seramiklerin örneklerinden Edirne Yeni Saray kazısında bulunan az miktardaki çok renk boyalı seramik parçasında bezemeler kısmen seçilebilmektedir. Bu seramiklerde 
kobalt mavi yine en sık kullanılan renktir. Siyah renk kontur rengi iken diğer renkler dolgu rengi olarak kullanılmıştır. $\mathrm{Bu}$ renkler arasında dikkat çeken bir renk mercan kırmızısıdır. Tarihlendirilebilen erken örneklerine Süleymaniye Camisi ve Hürrem Sultan Türbesi'ndeki çiniler gösterilmektedir (Raby, 1989a: 58; Süslü, 1996: 156). Diğer renklerle birlikte bir uyum içinde kullanılan mercan kırmızısı yüzyılın ikinci yarısında ve 17. yüzyıl başlarında parlak ve canlı iken daha sonra renk matlaşarak kahverengiye dönüşmüştür. 17. yüzyıl ilk çeyreğinden sonra da çizimler daha da zayıflaşmış, ayrıntılar azalmıştır (Lane, 1957a: 58; Lane, 1957b: 277).

Yeni Saray Kazısı çok renkli seramiklerinde en belirgin bitkisel motiflerden biri olan ve 16. yüzyılda dülbend lalesi olarak adlandırılan lale, Osmanlı sanatında oldukça popülerdir. (Raby, 1989c: 223). 16. yüzyılda ilk olarak yazma eserlerde, kumaş sanatı ve taş işçiliğinde dikkat çeken bu motifin en görkemli örnekleri çini ve seramiklerde karşımıza çıkmaktadır (Turan Bakır, 1999: 207). Lale motifi Anadolu Selçuklu Dönemi'nde de el sanatlarında sevilerek kullanılan bir motif türüdür (İrepoğlu, 2017: 186). Beylikler Dönemi'ne ait farklı tekniklerdeki lale motifleri genel olarak değerlendirildiğinde bu motiflerin 16. yüzyıl laleleri ile Selçuklu lale motifleri arasında yer almaları açısından önemlidir (Uçar \& Uçar, 2018: 22) Edirne Yeni Saray Kazısı 2013-2014 seramik buluntuları arasında bir adet boyun parçasında bu motife yer verilmiştir. Seramik tüm olmadığı için düzenleme tam anlaşılamasa da üç yapraklı laleler zemin renginde (beyaz) bırakılmış siyah konturla belirginleștirilmiştir (II:11). Dikey yönlü her bir lalenin arasında da yine siyah konturlu bir alanda, dilimli madalyonlar içerisinde tam anlaşılamayan çiçek motiflerine yer verildiği kısmen anlaşılabilmektedir. Lale ve diğer motif dönüşümlü yerleştirilerek silindirik formlu boyna hareket kazandırılmıştır. Bezemeler en üstte siyah çizgiyle oluşturulmuş, içinde spiral motiflerinin yer aldığı dar bordürle sonlandırılmıştır. Benzer kompozisyon düzenlemesinin yer aldığı seramikler daha önceki dönem kazılarında da ele geçirilmiştir. Dış yüzleri bezemeli seramik parçalarında da ağız kenarının ya da boyun başlangıcının dar bordürlerle bezendiği görülmektedir (III:1820). Örneklerden birinde zikzak motifleriyle bordür içerisinde üçgen alanlar oluşturulmuş ve bu üçgenlerin içerisi yine kırmızı beneklerle süslenmiştir (III:18). Benzer düzenlemenin görüldüğü diğer bir bordürde ise dilimli zikzaklar ile bordür hareketlenmiş zikzakların içi ise bu defa siyah noktalarla belirginleştirilerek yarım çiçek görünümü verilmiştir (III:20). Diğer bir parçada ise bordür içerisi 
siyah konturlu ve yeşil renk dolgulu zencirek motifleriyle bezenmiştir (III:19). Zencirek motifi daha sade olarak bir boyun parçasında da yer almaktadır (II:17). Bir adet tabak kenar parçasında gövdedeki kırmızı renkli motif tam seçilemese de ağız kenarında dar bir bordür oluşturulmuştur. Bordür içerisinde aynı tipte, kırmızı ile vurgulanmış yarım çiçek motifleri yerleştirilmiştir (II:12). Benzer vurgulama bir gövde parçasında karşımıza çıkmaktadır. Siyah konturlu bir yaprak motifinin içi kırmızı beneklerle bezenmiştir (II:14).

Naturalist üslupta gül ve sümbül motifinin görüldügü süsleme ise benzeri İznik örneklerinden farklılık göstermemektedir. İznik çini ve seramiklerinde genel olarak gül, lale, karanfil ve sümbül natüralist üslupta tasvir edilmiştir. Gül motiflerinin çini ve seramiklerde düzenlenişlerinde farklılıklar görülebilmektedir. Çinilerde tam karşıdan dilimli dairesel motifler şeklinde işlenirken, seramiklerde genellikle profilden gösterilmiştir. Bu motifin, yanlarındaki goncalar ve yapraklarla tanınabilirliği artmıștır (Demiriz, 1996: 49). Edirne Yeni Saray buluntusundaki gül motifi tam olmasa da, kırmızı renkli goncagül ve damarları, yine kırmızı ile belirginleştirilmiş yeşil yaprakları bir gül motifinin olduğunu göstermektedir (II:13). Aynı parça üzerindeki sümbül motifi de dikkate alındığında gül ile sümbülün dönüşümlü olarak kullanıldığı anlaşılmaktadır. Siyah konturlu ve yeşil renkli bir dal üzerindeki sümbül çiçekleri dört taç yapraklıdır ve bu uygulama çinilerde de benzerdir (Sinemoğlu, 1996: 134). Saray seramiğindeki bu motif görünüşüyle İznik çini ve seramiklerindeki sümbüllerin görünüşünden farklılık göstermemektedir.

Çok renkli seramiklerden birinin gövde parçasında ise balıkpulu motifleri oldukça belirgindir. Siyah konturlu ve yeşil renk dolgulu bu motifin hâkim olduğu bezemede ortada türü tam anlaşılamayan içi boş bırakılmış ve kırmızı ile belirginleştirilmiş bir yaprak motifi bulunmaktadır (II:15). Balık pulu motifinin kullanım sıklığı dikkate alındığında hemen hemen farklı coğrafyalardaki birçok kültürde mimariden el sanatlarına kadar birçok alanda bezeme unsuru olarak yer bulmuştur. İşlenişlerinde küçük farklılıklar olmakla birlikte genel olarak birbirlerine benzemektedir. Hayvan figürlerinden bitkisel motiflere ya da zadece zemini doldurmak için kullanılan bu motif İznik seramiklerinde sıklıkla kullanılmıştır (Altun \& Demirsar Arl,, 2001: 396, Res.11; Uçar, 2014: 218). Edirne Yeni Saray seramiğindeki motif de diğer İznik seramiklerindeki balık pulu motiflerinin işlenişiyle aynıdır. 
Kütahya seramikleri (Tablo III:21-26;Tablo IV)

Her ne kadar Kütahya çini ve seramikleri 18. yüzyılda tanınır olsa da, Kütahya'daki kazı çalışmalarında bulunmuş seramikler, bu kentteki seramik üretiminin İznik ile çağdaş olabileceğini ortaya koymuştur (Şahin, 1981a: 259-286; Şahin,1981b: 150). Kütahya'da üretilmiş çinilerde olduğu gibi seramiklerde de İznik'e göre belirgin farklılar dikkati çekmektedir. Kütahya seramikçiliğinde daha çeşitli formlar daha zengin renklerle daha naif işlenmiștir (Demirsar Arll, 2007: 337) 2013-2014 yılı Edirne Yeni Saray Kazısı'nda Kütahya işi seramikler de bulunmuştur. Kâse ve fincan türündeki açık formlu kaplardan birkaçının biçimi kısmen anlaşılabilmektedir. Kâse formundaki kap konik gövdelidir (III:21). Bir adet fincan da dışa açılan halka kaideli, konik gövdeli ve basit yuvarlak ağız kenarlıdır (III:23). Diğer bir fincan parçasının kaidesi ise diğer kaidelere göre daha yüksek tutulmuştur (IV:28). Kâse parçasının formu tam anlaşılamasa da iç yüzde merkezdeki bombe ile diğer örneklerden ayrılmaktadır. Kâse şekillendirildikten sonra kâse formlu çok küçük kabara merkeze ters kapatılmış ve kâseye şifa tası ya da hamam tasına benzer bir görünüm kazandırılmıştır. Kimi zaman bu kabaranın içerisine küçük objeler konularak ses çıkarmaları sağlanmıştır (Carswell \& Dowsett, 1972: 30). Bu özellik Kütahya kâseleri içerisinde sıklıkla görülebilmektedir (Carswell \& Dowsett, 1972: 34, Fig.16a; Baş, 2012: 29, Kat.1.48; Gök, 2015a: Kat.188-193).

Bezeme: Sıraltı boyama tekniği ile oluşturulmuş bezemeler kapların gerek iç gerekse dış yüzünde görülmektedir. İznik seramiklerinde olduğu gibi bezemeler tek ve çok renkli boyama olmak üzere iki tipte yapılmıştır. Renk paleti açısından İznik seramiklerindeki renklere ek olarak en dikkat çekici renklerden biri olan sarı gösterilebilir. Daha önceki dönemlerde farklı tekniklerle karşımıza çıksa da Kütahya çini ve seramiklerinin renk paletindeki en önemli renklerdendir. 18. yüzyılda yaygınlaşmaya başlayan ve Kütahyalı ustaların renk paletinde sıkça yer bulan bu rengin benimsenmesinde, bu yüzyılda ticareti Ermeni tüccarlar tarafından sıklıkla yapılan Hint kumaşları ile İtalya ve İran'daki kostümlerde oldukça popüler olan sarın rengin etkili olabileceği düşünülmektedir (Crove, 2007: 199-206; Kouymjian \& Berbérian, 2010: 65-89).

17. yüzyıldan itibaren çini ve seramiklerde sıkça karşılaşılan kahverengi de Kütahya seramiklerinde dolgu rengi olarak kullanılmıştır. Mavi ise yine İznik'te olduğu gibi yalnız ya da diğer 
renklerle birlikte kompozisyonda yerini almıştır. İznik seramikleriyle bezeme türü açısından benzerlikler gösterse de üslupsal özellikleri ile belirgin biçimde ayrılmaktadır. Kuşkusuz bu farklılıkta bezeme yapılan kabın formu oldukça etkilidir. Fincan ve kâse gibi tabaklara oranla daha küçük olan kaplarda şablonun seramik üzerinde yaratmış olduğu tekrar sistemi daha az hissedilmektedir. Kap boyutunun küçüklüğü kimi motiflerin seramik yüzeyinde daha az konumlandırılmasına etki etmiştir. Bu da daha geniş kaplardaki çoklu motif kopyalarının kompozisyondaki ağırlığının fincanlarda daha az hissedilmesine sebep olmuştur.

Bazı örneklerde Çin kompozisyonlarının etkisi sezilse de Kütahyalı ustaların bu kompozisyonları kendi seramiklerine aktarım yöntemleri, Kütahyalı seramikçilerin farklılığını ortaya koyan önemli özelliklerden biridir. Kompozisyonlar tema olarak benzese de motiflerin çizgisel özellikleri, seramiklerdeki Çin etkilerini oldukça zayıflatmıştır. Bu etkiyi belki de önemli derecede söndüren başka bir unsur ise, malzeme özelliklerine bağlı olarak sırın daha mat görünümlü olmasıdır. Bu da Çin porselenlerindeki keskin ya da sert görünümün Kütahya örneklerinde görülmemesine sebep olmuştur. $\mathrm{Bu}$ seramiklerde göze çarpan en önemli Çin etkisi seramiklerin dibinde Çin örneklerinde saltanat işaretlerini çevreleyen konsantrik halkalar, bu seramiklerde göze çarpan en önemli Çin etkilerindendir (Carswell, 1991: 52). Bu halkaların diplerde konumlandırılmasında bir standart yoktur. Bazılarında bu halkalara rastlanırken (IV:27) kimi örneklerde hiç halka bulunmamaktadır. Aynı düzenleme kaidelerin dış yüzünde de görülür. Kaideler yine ikili halka ile belirginleştirilmiştir (III:23;IV:29). Konsantrik halkaların karşımıza çıktığı diğer bir alan ise seramik içyüzüdür. Gerek merkez gerekse gövde başlangıcı çiftli halkalarla belirginleştirilmiş ve içleri çoğunlukla bitkisel motiflerle süslenmiştir (III:21,23;IV:27-29). Tıpkı İznik örneklerindeki gibi kabın dairesel formuna bağlı olarak düz çizgilerle meydana gelen bu halkaların ikili olarak görüldüğü son bölüm ise ağız kenarlarıdır (III:21,23). Kâse örneğinde ağız kenarı ikili çizgi ile belirginleştirilerek kap merkezindeki çizgiler ile birlikte seramik yüzünde bir uyum sağlanmıştır. Düz çizgilerin sınırlandırdığı yatay bordürler tıpkı İznik seramiklerinde olduğu gibi Kütahya seramiklerinde de karşılaşllan bir unsurdur. Kütahya üretimi seramiklerde bolca örneği olsa da Edirne Yeni Saray buluntularının sayısal azlığı ve seramiklerin sağlam ulaşamaması, bordür tiplerini saptamamıza engeldir. Kısmen sağlam ulaşabilmiş bir adet fincanın dış yüzündeki kompozisyon düzenlemesi oldukça ilginçtir. Gövde 
başlangıcı ve ağız kenarında mavi çizgilerle yatay bir bordür oluşturulmuş, bu bordürlerin içleri ise mavi renkli çapraz taramalarla bezenmiştir (III:23). Gövdede oluşan geniş bordür ise düz kahverengi boyalıdır. Dar bordürlerdeki bezemeler aynı dönem içerisinde daha geniş alanda irdelenirse, farklı bölgelerdeki atölyelerde de benzer bezemelerin uygulandığı anlaşllabilir. Daha geniş ya da daha dar olarak bazı Kütahya seramiklerinde yer alan bu taramalı bordürler Çanakkale seramikleri içerisinde de sık tercih edilen bir bordür düzenidir (Doğer, 2008: 41, Res.1d; Doğer, 2009: 54, Res.1). İşlenişlerinde farklılıklar seçilse de yaklaşık aynı yüzyıllarda üretim yapan iki farklı bölgedeki atölyedeki motif uyumuna örnek gösterilebilir. Benzer bezeme özelliğinin özellikle 18. yüzyılda toplumun büyük kesimi tarafından benimsenmiş ve toplumun günlük yaşamda en sık kullandığı objelerden olan lülelerde de görülmesi beğeni ve bezeme repertuvarındaki uyumu daha da perçinleștirmektedir. Gövde ortasında oluşan geniş bordürdeki renk düzenlemesi ise oldukça ilginçtir. Bu düzenleme 18. yüzyıldaki dış yüzleri sadece kahverengi olan porselenlerle yakınlık göstermektedir. Bu örnek, dış yüzdeki taramalı bordürlerden dolayı Uzakdoğu- Kütahya benzerliğini tam vurgulamasa da, içyüzü renksiz dış yüzünün tamamı kahverengili olan bir adet fincan (IV:30), farklı bir durum ortaya koymaktadır. Bu fincan, Çin örneklerinin dünya pazarına hâkim olduğu bir dönemde, Kütahyalı ustaların bu ticaret içerisinde kalma çabası ve Çin örnekleriyle yarışının bir temsili olarak gösterilebilir. Bu ve benzeri örnekler çok ya da tek renkli Kütahya seramikleri içinde oldukça sade olsalar da, satıcının vitrininde Çin örnekleriyle birlikte sergilendiğinde, yerli ve ithal ayrımını yapabilen bir alıcının zihnini karıştırdığı muhakkaktır. Dış yüzü kahverengili bu fincanda olduğu gibi bazı Kütahya seramiklerinde bezemeye rastlanılmaz. Seramik şeffaf renksiz ya da renkli sır ile sırlanıp satışa sunulmuștur. Suna ve İnan Kıraç Vakfı koleksiyonundaki örnekler de dikkate alındığında bu tür seramiklerin gerek iç pazar gerekse dış pazarda yer buldukları anlaşılmaktadır (Gök, 2015b: Kat.40,41)

Seramikler günümüze tüm ulaşamadığı için geometrik ve bitkisel motiflerin dağılımı kompozisyon içinde tam seçilememektedir. Bitkisel desenler Kütahya seramikçiliğindeki bezeme repertuvarından bir takım örnekleri bize kısmen yansıtmaktadır. Seramiklerin dış ya da iç yüzünde bazen geometrik biçimlerle sınırlanmış bazen de hiç sınırlandırmadan işlenmiş bu bezemelerde çoğunlukla motifin hangi bitkiye ait olduğu tam 
seçilemez. Örnek olarak, bir adet fincanın dış yüzünün tamamının kıvrımlı dallar ve bu dallar üzerindeki yapraklarla bezendiği görülmektedir (IV:31). Diğer bir seramik parçasında ise gövdede mavi konturlu bir madalyon ve bu madalyonun yanında testere dişli stilize bir bitkisel motife yer verilmiştir (III:21). Bazı örneklerde ise fincan iç yüzünde merkez, tek dallı stilize bir çiçekle belirginleştirilmiştir (IV:29,32). Seramik içyüzünde taç yaprakları yeşil ve sarı renk dolgulu bir yıldız çiçeğinin verilişi ise Kütahyalı ustanın kompozisyon kurgusundaki yetisini bize göstermektedir. Merkezdeki kabara siyah konturla çevrelenmiş ve bu konturun etrafına üçgen biçimli yapraklar yerleştirilmiştir. Merkezdeki çiçek, taç yapraklar arasındaki kırmızı benekli dallar ile daha da hareketlendirilmiştir. Benzer düzenlemeler Kütahya seramiklerinde sıklıkla görülmektedir (Akalın \& Yılmaz Bilgi, 1997: Kat.94,105; Gök, 2015c: 69, Tablo 4.3).

Kütahya seramikleri arasında en dikkat çekici buluntular iç yüzlerinde natürmortların yer aldığı fincan parçalarıdır $(I V: 27,28)$. Zemin çiftli konsantrik halka ile belirginleştirilmiş ve bu halkaların içlerine pedestallı, kulplu bir sepet yerleştirilmiştir. Sepetlerin içerisi de türü anlaşılmayan çiçeklerle doldurulmuştur. Bir sepette kulp taramalı iken diğerinde boş bırakılmıştır. Sepetlerin işlenişi ve içerisindeki çiçeklerin öbek öbek yerleştirilişi, kompozisyon tasarımının Çin porselenlerinden alındığını göstermektedir. Edirne Yeni Saray'da daha önceki dönemde bulunmuş bir porselen fincan örneğinin tasarımı bu etkileşimin delili olarak sunulabilir. Dolayısıyla natürmortların seramik içerisindeki konumu ve sepet içerisindeki motiflerin benzerliği Çin porselenlerinin Kütahyalı ustaları etkilediğini göstermekle birlikte, etkileşim problemi de aynı kazı buluntuları içerisinde çözümlenmektedir (Uçar, 2014: 151). Diğer bölgelerdeki kazılarda bulunan örnekler de dikkate alındığında bu kompozisyon düzenlemesinin Kütahyalı ustalarca oldukça benimsendiğini söyleyebiliriz (Gök, 2015a: 31, Tablo 5; Buğdaycı, 2018: 544, Fot.24).

Kütahya fincanlarında dikkat çeken diğer bir süsleme, görülmesi en güç noktada olan ve birçoğunun gizemi hala çözümlenememiş işaretlerdir (III:25;IV:28). Usta ya da atölye işareti oldukları düşünülen bu işaretlerin, yazının yanında yıldız, çarpı, taramalı baklava, çapraz iki kılıç gibi çeşitleri bulunmaktadır (5). Fincanların büyük çoğunluğunda işaret olmasının sebebi ustaların ürettikleri fincan başına ücret almalarına ve ürettikleri fincan sayısının belli olmasına yönelik olabileceği gösterilmektedir 
(Yenişehirlioğlu, 2013: 334). Edirne Yeni Saray buluntularının bir kısmında bu işaretler bulunmaktadır. Bu motifler de stilize yıldız ve çiçek motifleri biçimindedir ve diğer kazılarda bulunan fincanların motiflerinden farklılık göstermemektedir.

\section{Sonuç}

2013 - 2104 yılı kazı sezonunda Edirne Yeni Saray'da bulunan İznik ve Kütahya seramikleri daha önceki dönemde bulunan seramiklerle teknik, biçim ve kompozisyon açısından benzerlikler taşımaktadır. Sıraltı tek renk ve sıraltı çok renk boyalı olmak üzere iki gruba ayrılan İznik seramiklerinin sarayda sıklıkla tercih edilen yerli ürünlerden oldukları 2013 - 2014 ve daha önceki dönem kazılarında bulunan seramiklerden anlaşılabilmektedir. 2013-2014 buluntuları günümüze tüm ulaşamasa da kendine has kompozisyonları ile buluntular içerisinde önemli bir grubu oluşturur. Milet Tipi seramiklerden sonra üretilmeye başlanan mavi-beyaz seramikler, Çin porselenlerinin Osmanlı sarayında sıklıkla tercih edilmesinden önceki en gözde seramikler olarak gösterilebilir. Çok renk boyalı İzniklerin ise Osmanlı'nın kendine has saray üslubuyla adeta modası geçmiş 15 . yüzyıl Çin porselenlerinin kompozisyonlarına savaş açtığı söylenebilir. Kobalt mavinin yanına eklenen firuze, yeşil, mor, siyah ve mercan kırmızısı ile yapılmış natüralist çiçeklerin yer aldığı İznik seramikleri adeta İznik seramikçiliğinde bahar mevsiminin yaşandığını simgelerken, kahverengiye dönüşmüş kırmızı renkli ve daha kaba bezemeli seramikler İznik seramikçiliğinde güz mevsimini yani sonun başlangıcını simgelemektedir. 18. yüzyıla ait Kütahya seramikleri teknik olarak İzniklerle aynı çizgide olsa da motif ve kompozisyon tasarımı saçısından bu çizginin dışında oldukları söylenebilir. Bazı özellikleri ile Çin örneklerini yansıtsalar da motiflerin işlenişi ile kendilerine has bir üsluplarının oldukları görülebilmektedir. Gerek İznik gerekse Kütahya seramiklerinin benzerleri dikkate alındığında, saray ve saray saray dışında ortak özelliklere sahip seramiklerin kullanıldığı anlaşılmaktadır.

Notlar:

1-Edirne'de bulunan Milet Tipi tabaklar hakkında bkz., (Yllmaz, 2012)

2- Edirne Tarihi ve Edirne Sarayı ile ilgili daha fazla bilgi için bkz., Peremeci, 1939; Aslanapa, 1949; Ayverdi, 1953; Osman, 1957; İnalcık, 1965; Gökbilgin, 1994; Kazancıgil, 1994; Emecen, 1998. 
3-Edirne Yeni Saray'da yapılan kazı çalışmaları ve bu çalışmalarda bulunan küçük buluntularla ilgili bkz., Öz, 1965; Cantay, 2001a; Cantay, 2001b; Cantay, 2002a; Cantay, 2002b; Cantay, 2003; Cantay, 2005; Özer, 2012; Özer, 2013a; Özer, 2013b; Özer, Dündar, Güner, \& Uçar, 2016a.

4- $\mathrm{Bu}$ isimlendirme ve üslup ile ilgili ayrıntılı bilgi için bkz, (Raby, 1989b)

5-Bu sembollerin çeşitleri ve bunlar hakkında daha fazla bilgi için bkz., Carswell \& Dowsett, 1972; Kürkman, 2005; Gök, 2015a: 31,32 .

\section{Kaynakça}

Akalın, Ş., Bilgi, H. (1997). Suna ve İnan kıraç Koleksiyonunda Kütahya Seramikleri Yadigar-ı Kütahya. İstanbl: Suna-İnan Kıraç Akdeniz Medeniyetleri Araştırma Enstitüsü.

Altun, A. (1991). İznik Çini ve Seramikleri. Sadberk Hanım Müzesi Türk Çini ve Seramikleri , İstanbul: Sadberk Hanım Müzesi, 8-48

Altun, A., \& Demirsar Arlı, B. (2001). İznik Çini Fırınları Kazısı 1999 Çalışmaları. 22. Kazı Sonuçları Toplantısı, 2, Ankara: Kültür Bakanlığl, ss. 387-396.

Aslanapa, O. (1949). Edirne'de Osmanlı Devri Âbideleri. İstanbul.

Atıl, E. (1987). The Age of Sultan Süleyman the Magnificent. Washington: National Gallery of Art, Washington.

Ayverdi, E. H. (1953). Fâtih Devri Mimarisi. İstanbul.

Baş, G. (2012). Bitlis Kalesi Kazısı Sırlı Seramikleri (2004-2012). Ankara: Pegem Akademi.

Bilgi, H. (2009). Ateșin Oyunu sadberk Hanım Müzesi ve Ömer M.Koç Koleksiyonlarından İznik Çini ve Seramikleri. İstanbul: Vehbi Koç Vakfi.

Buğdaycı, B. (2018). Kütahya Çini Müzesi'nde Sergilenen 18. yüzyıl Kütahya Üretimi Fincanlar. Kütahya Müzesi 2017 Ylllı̆̆ı, V, İstanbul, T.C. Kütahya Valiliği, ss.525-545.

Cantay, G. (2001a). Edirne Yeni Sarayı (Matbah-ı Amire Kazısı) 1999. 22. Kazı Sonuçları Toplantısı, 2, Ankara: Kültür Bakanlığı, ss. 439448.

Cantay, G. (2001b). Edirne Yeni Saray Kazısı (1999-2000) Keramik Buluntuları. V. Ortaçă̆ Türk Dönemi Kazı ve Araştırmaları Sempozyumu Bildiriler Ankara: Hacettepe Üniversitesi, Edebiyat Fak. Sanat Tarihi Bölümü, ss. 145-160.

Cantay, G. (2002a). Edirne Yeni Saray Kazısı, 2000. 23. Kazı Sonuçları Toplantısı, 1, Ankara: Kültür Bakanlığı, ss. 29-40. 
Cantay, G. (2002b). Edirne Yeni Saray Kazısı'nda Bulunan Figürlü Keramikler. Uluslararası Sanat Tarihi Sempozyumu Prof.Dr. Gönül Öney'e Armağan, 10-13 Ekim 2001, Bildiriler İzmir: Ege Üniversitesi, Edebiyat Fakültesi, ss. 176-178.

Cantay, G. (2003). Edirne Yeni Saray Kazısı, 2001. 24. Kazı Sonuçları Toplantısı, 1 Ankara: Kültür Bakanlığı, ss. 29-38.

Cantay, G. (2005). Edirne Yeni Saray Kazısı Lüle Buluntuları. Fen Edebiyat Dergisi 7/1, ss.108-120.

Carswell, J. (1991). Kütahya Çini ve Seramikleri. Sadberk Hanım Müzesi Türk Çini ve Seramikleri, İstanbul: Vehbi Koç Vakfı, ss.49102.

Carswell, J., \& Dowsett, C. (1972). Kütahya Tiles and Pottery from the Armenian Cathedral of st James, Jerusalem, II. London: Oxford University Press.

Crove, Y. (2007). Kütahya Bowl with a Lid in the Walters Art Museum. The Journal of the Walter Arts Museum, 64/65, pp.199206.

Demiriz, Y. (1996). Osmanlı Keramik ve Çini Sanatında Gül Terminolojisi ve Tanımı. Prof. Dr. Şerare Yetkin Anısına Çini Yazıları İstanbul: Sanat tarihi Derneği, ss. 47-58.

Demirsar Arlı, V. B. (2007). Kütahya Çiniciliği. Anadolu'da Türk Devri Çini ve Seramik Sanatı, İstanbul: T.C. Kültür ve Turizm Bakanlığı, ss. 329-345.

Doğer, L. (2008). İzmir Agorası Kazılarından Çanakkale Seramikleri ve Diğer Talep Noktaları. Çanakkale Seramikleri Kolokyumu Bildirileri, Antalya: Suba-İnan Kıraç Akdeniz Medeniyetleri Araştırma Enstitüsü, ss. 30-46.

Doğer, L. (2009). İzmir Agorası Kazılarından 17. - 19. Yüzyıl Seramik Buluntuları. Sanat Tarihi Dergisi.

Emecen, F. M. (1998). Tarih Koridorlarında Bir Sınır Şehri: Edirne. Edirne: Serhattaki Payitaht. İstanbul.

Gök, S. (2015a). Smyrna (İzmir) Agorası'nda Osmanlı İzleri Kütahya Seramikleri (2007-2014 Dönemi). İzmir: İzmir Büyük Şehir Belediyesi.

Gök, S. (2015b). Suna ve İnan kıraç Vakfı Koleksiyonu Kütahya Çini ve Seramikleri 2. İstanbul: Pera Müzesi.

Gök, S. (2015c). İzmir'in Ticari Yaşamında Osmanlı ve Avrupa Seramiklerinin Yeri. Smyrna/İzmir Kazı ve Araştırmaları I. Calıştay Bildirileri, İstanbul: Ege Yayınları, ss. 61-78.

Gökbilgin, M. T. (1994). Edirne. DİA,10, İstanbul, ss. 431-442. 


\section{Hasan UÇAR}

İnalcık, H. (1965). Edirne'nin Fethi 1361. Edirne: Edirne'nin 600. Fetih Yıldönümü Armağan, Ankara, ss. 137-159.

İrepoğlu, G. (2017). Lale -Doğada, Tarihte, Sanatta. İstanbul: Yapı Kredi.

Kazancıgil, R. (1994). Edirne Sarayı ve Yerleşim Planı. Edirne.

Kouymjian, H., \& Berbérian, I. (2010). Le rôle des potiers arméniens de Kütahya dans l'histoire de la céramique ottomane. Des serviteurs fidèles - Les enfants de l'Arménie au service de l'Etat turc, pp.65-89.

Kürkman, G. (2005). Toprak, Ateș, Sır, Tarihsel Gelişimi, Atölyeleri ve Ustalariyla Kütahya Çini ve Seramikleri. İstanbul: Suna ve İnan Kıraç Vakfı Yayını.

Lane, A. (1957a). Later Islamic Pottery. London.

Lane, A. (1957b). The Ottoman Pottery of Iznik. Ars Orientalis, Vol. 2, pp. 247-281.

Osman, R. (1957). Edirne Sarayı (Yayınlayan S.Ünver). Ankara.

Öz, T. (1965). Edirne Yeni Sarayı'nda Kazı ve Araştırmalar. Edirne'nin 600. Fethi Yıldönümü Armağan Kitabı, Ankara: Türk Tarih Kurumu, ss. 217-222.

Özer, M. (2012). Edirne Yeni Saray Kazısı, 2009-2010 Yılı Çalışmaları. Uluslararası Katılımlı XV. Ortaçağ ve Türk Dönemi Kazıları ve Sanat Tarihi Araştırmaları Sempozyumu, 2, Eskișehir, ss. 615626.

Özer, M. (2013a). Edirne Yeni Saray Kazısı, 2010 Yılı Çalışmaları . 33. Uluslararası Kazl, Araștırma ve Arkeometri Sempozyumu Bildirileri, 2 , Ankara: Kültür Bakanlığı, ss. 287-312.

Özer, M. (2013b). Edirne Yeni Saray (Saray-ı Cedid-i Amire) Kazısı 2011 Yılı Çalışmaları. 34. Uluslararası Kazı, Araştırma ve Arkeometri Sempozyumu Bildirileri, 3, Ankara: Kültür Bakanlığı, ss. 347-360.

Özer, M., Dündar, M., Uçar, H., Ayhan, G., \& Güner, M., (2016a). Edirne Yeni Saray Kazısı (Saray- ı Cedîd- i Âmire) 2011 Yılı Çalışmaları. Sanat Tarihi Dergisi, XXIV/1, ss. 73-106.

Özer, M., Dündar, M., Güner, M., \& Uçar, H. (2016b). Edirne Yeni Saray Kazısı (Saray- ı Cedîd- i Âmire) 2014 Yılı Çalışmaları. 37. Kazı Sonuçları Toplantısı, 3, Ankara: Kültür ve Turizm Bakanlığı, ss.595-622.

Özkul Fındık, N. (2001). İznik Roma Tiyatrosu Kazı Buluntuları 19801995 Arasındaki Osmanlı Seramikleri. Ankara: Kültür Bakanlığı.

Peremeci, O. N. (1939). Edirne Tarihi. İstanbul. 
Raby, J. (1989a). İznik Çinisinin Yapılışı. İznik (s. 49-63). içinde London: Alexsandria Press.

Raby, J. (1989b). 1480-1560 İznik Seramiğininin Büyümesi ve Gelişmesi. İznik, London: Alexandria Press London, pp.76-215.

Raby, J. (1989c). İznik Seramiğinin Olgunluğu ve Bozulması. İznik London, ss. 218-369.

Sinemoğlu, N. (1996). Onaltıncı Yüzyıl Çinilerinde Motif Zenginliği. Prof. Dr. Şerare Yetkin Anısına Çini Yazıları, İstanbul: Sanat Tarihi Derneği, ss. 125-155.

Süslü, Ö. (1996). XVI. Yüzyll Osmanlı Seramiklerinde Sır Altına Uygulanan Kırmızı Rengin İlk Örnekleri. Prof. Dr. Şerare Yetkin Anısına Çini Yazıları, İstanbul: Sanat Tarihi Derneği, ss. 155-160.

Şahin, F. (1981a). Kütahya-Çini Seramik Sanatı ve Tarihi'nin Yeni Buluntular Açısından Değerlendirilmesi. Sanat Tarihi Yıllı̆̆ı (1979-80) 9-10, ss.259-286.

Şahin, F. (1981b). Kütahya Seramik Teknolojisi ve Çini Fırınları Hakkında Görüşler. Sanat Tarihi Yıllığı XI, ss.133-164.

Turan Bakır, S. (1999). İznik Çinileri ve Gülbenkyan Koleksiyonu. Ankara: Kültür Bakanlığı.

Turan Bakır, S. (2007). Osmanlı Sanatında Bir Zirve İznik Çini ve Seramikleri. Anadolu'da Türk Devri Çini ve Seramik Sanatı, İstanbul: T.C. Kültür ve Turizm Bakanlığı, ss. 279-305.

Uçar, H. (2014). Edirne Yeni Saray Kazısı Seramikleri (Yayımlanmamış Doktora Tezi). İzmir.

Uçar, H., \& Uçar, A. (2018). Tire Kutu Han Kazısı Beylikler ve Osmanlı Dönemi Seramikleri. Sanat Tarihi Dergisi, XXVII/1, ss.1-33.

Yenişehirlioğlu, F. (2013). Fincanınızda Ne var?: Osmanlı döneminde Günlük Yaşam, Sosyal Değişimler ve Fincan Tipleri. Yemekte Tarih Var Yemek Kültürü ve Tarihçiliği. içinde İstanbul: Tarih Vakfi Yurt Yayını.

Yılmaz, G. (2012). Edirne Müzesi Osmanlı Seramikleri, Zindanaltı Buluntuları. Edirne. 


\section{Hasan UÇAR}
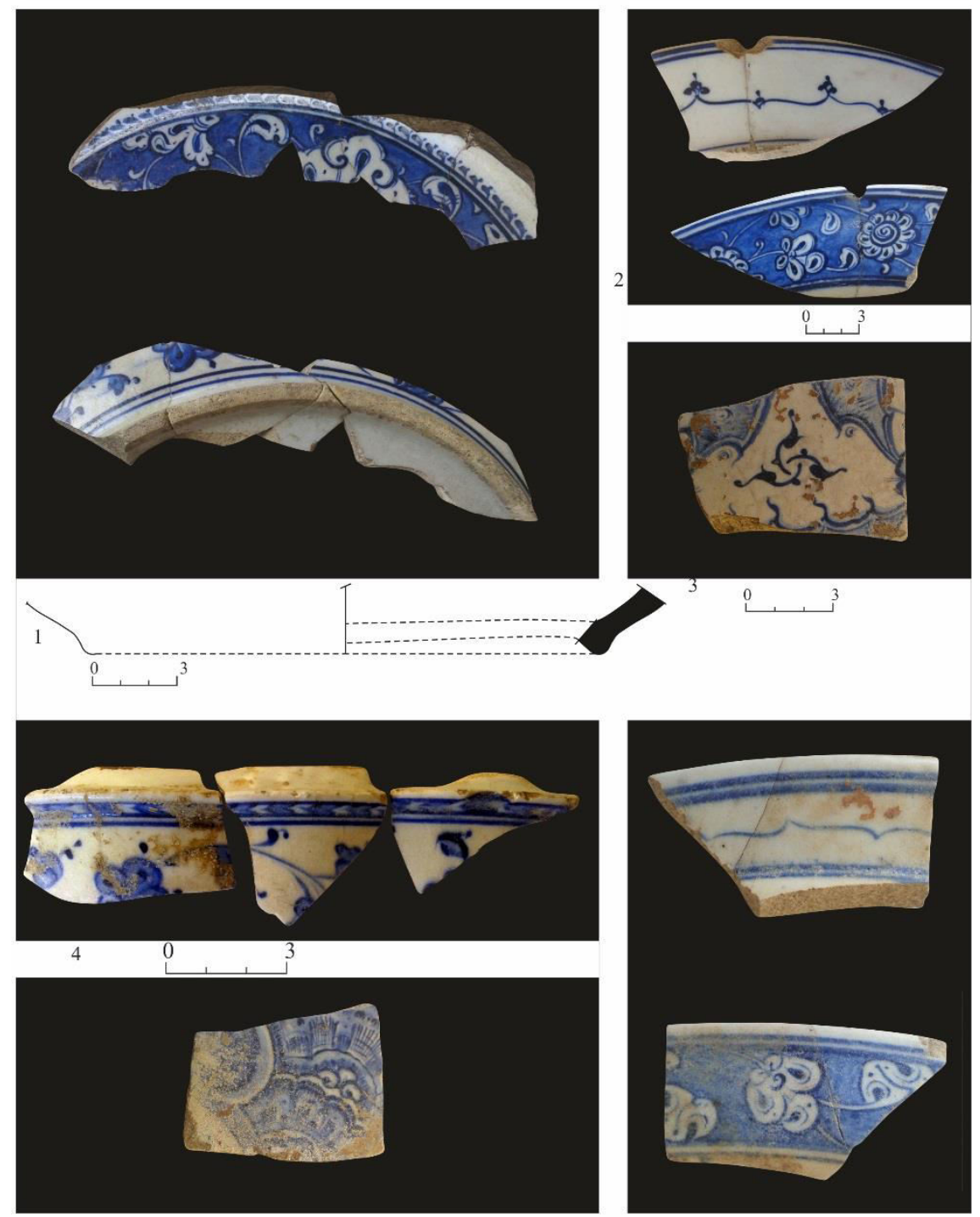

5

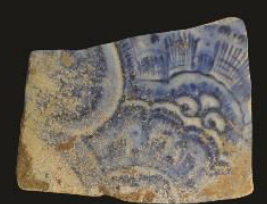

60

3

382 | Celal Bayar Üniversitesi Sosyal Bilimler Dergisi - Cilt: 17, Sayı: 3, Eylül 2019 
2013-2014 Yılı Edirne Yeni Saray Kazısı İznik ve Kütahya Seramikleri

Tablo I:Mavi-Beyaz İznik seramikleri (15. yüzyıl sonu-16. yüzyıl ilk çeyreği) 


\section{Hasan UÇAR}

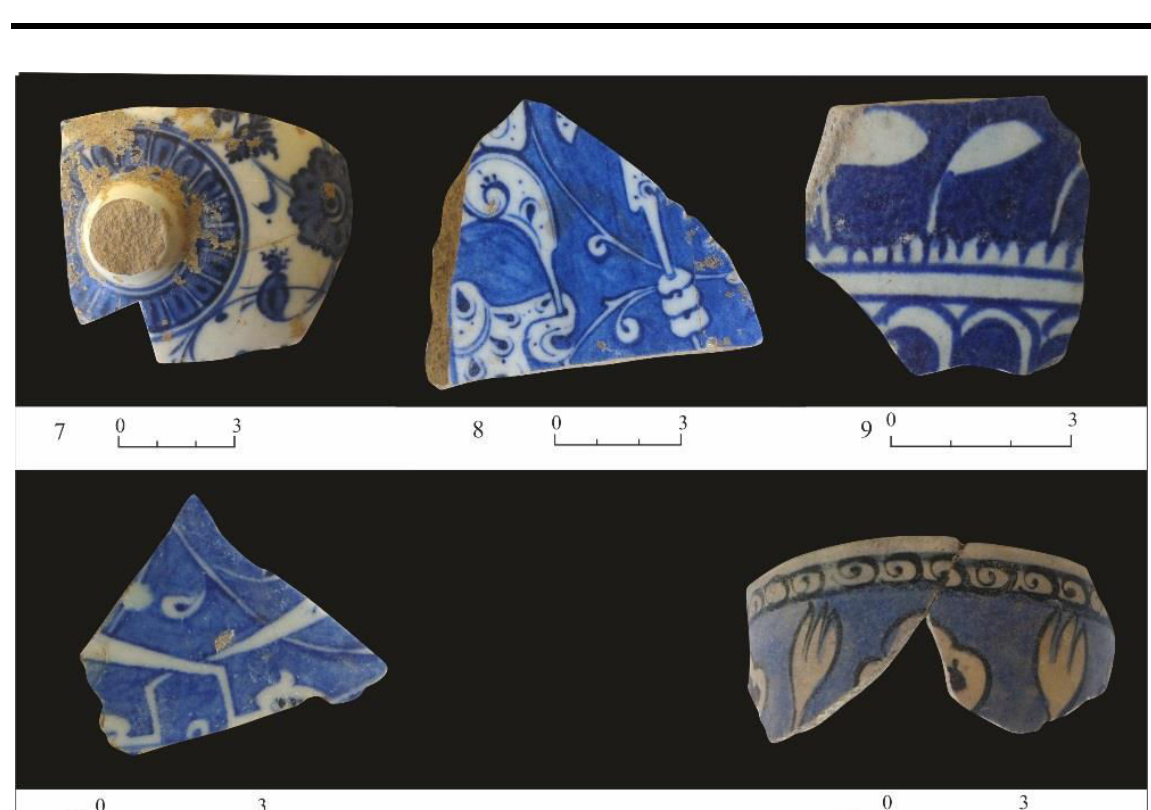
$10^{0}\llcorner, \quad\rfloor^{3}$
$11 \stackrel{0}{\longleftarrow, \underbrace{3}}$
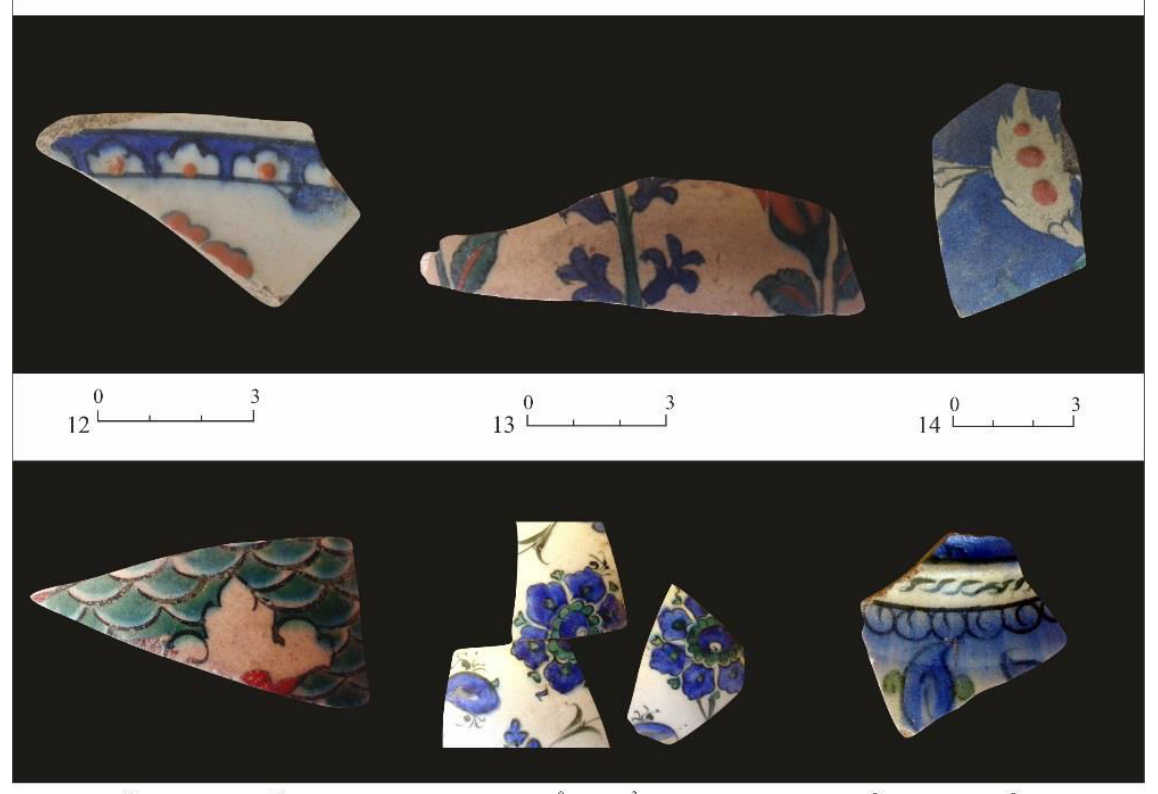

$15 \quad 0 \quad 3$

$16 \stackrel{0}{-\cdots}$

$17 \stackrel{0}{\llcorner}$

Tablo II: İznik mavi beyaz seramikleri 7-10 (15. yüzyll sonu-16. yüzyıl ilk çeyreği), İznik çok renkli seramikler 11 (16. yüzyıl 2. çeyreği);12-17 (16. yüzyıl 2. yarısı).

384 | Celal Bayar Üniversitesi Sosyal Bilimler Dergisi - Cilt: 17, Sayı: 3, Eylül 2019 
2013-2014 Yılı Edirne Yeni Saray Kazısı İznik ve Kütahya Seramikleri
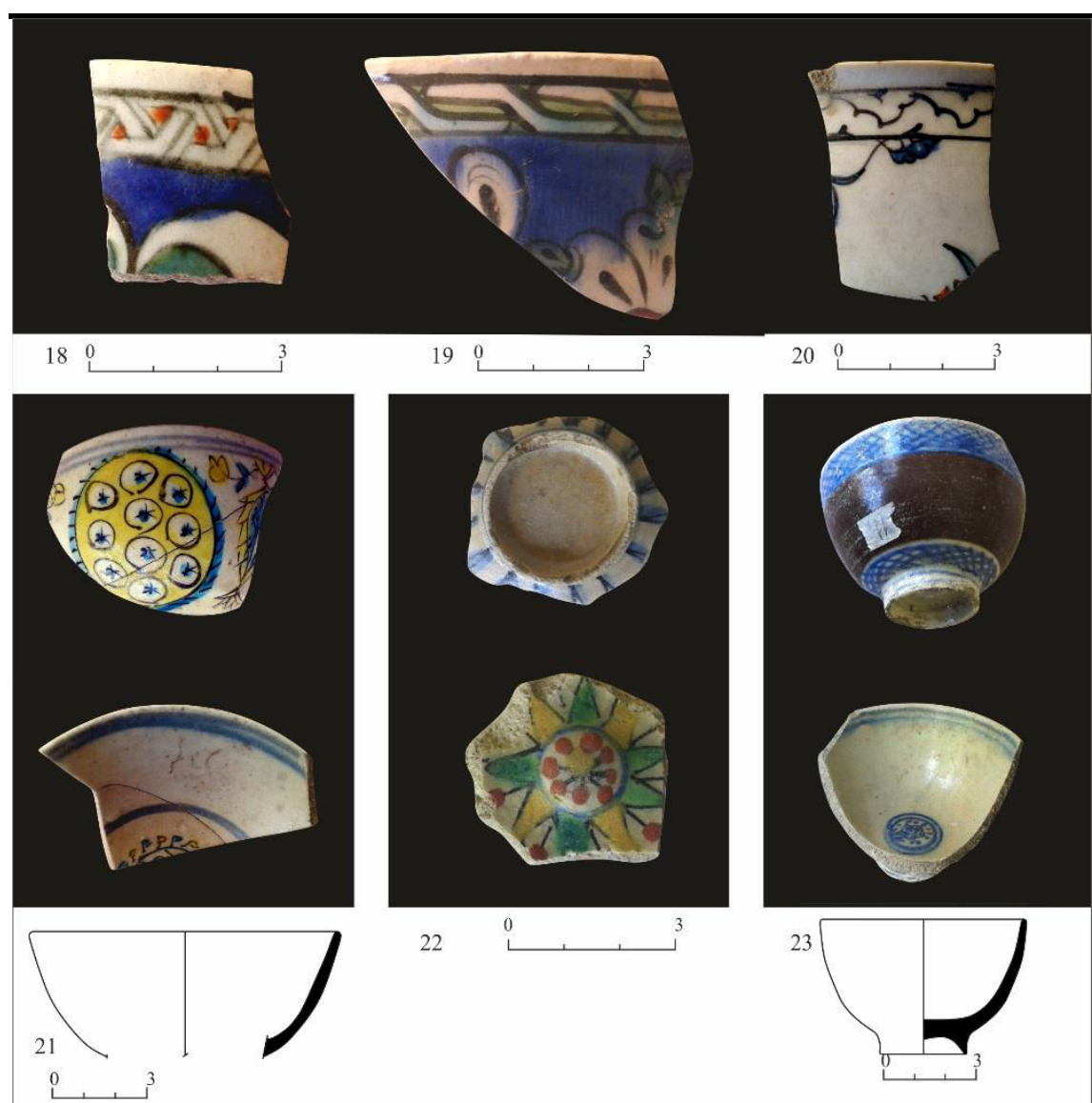

19

200

3
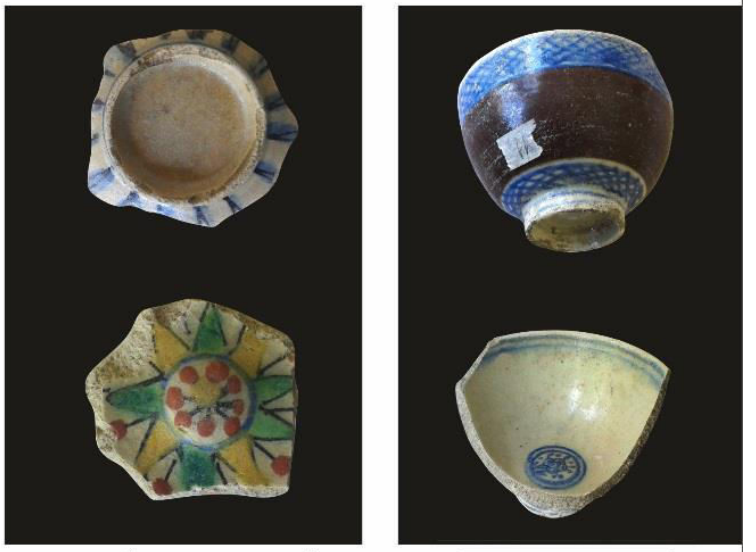

22 3
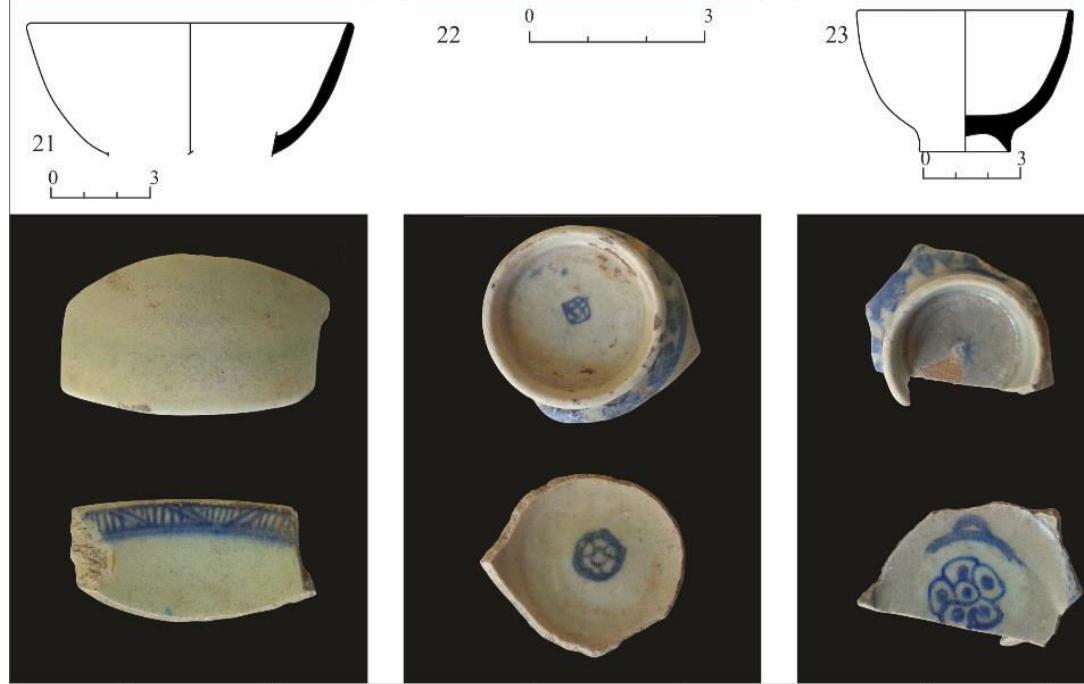

240

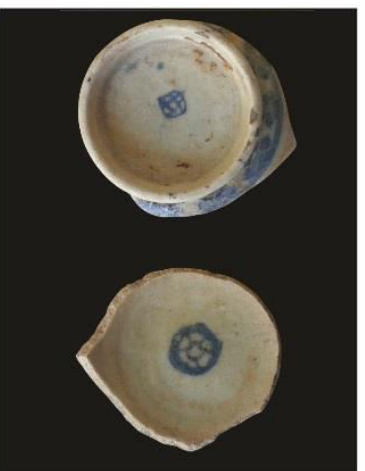

$25 \quad 0$

3

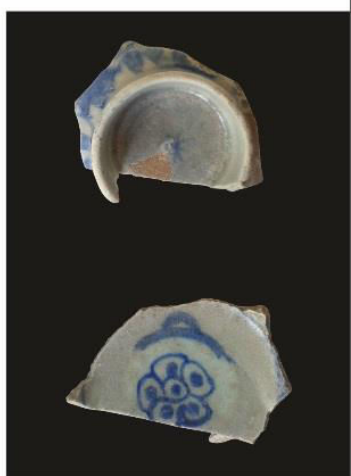

$26 \quad 0$

Tablo III: İznik çok renkli seramikler 18-20 (16. yüzyıl 2. yarısı); Kütahya seramikleri 21-26 (18. yüzyıl). 


\section{Hasan UÇAR}

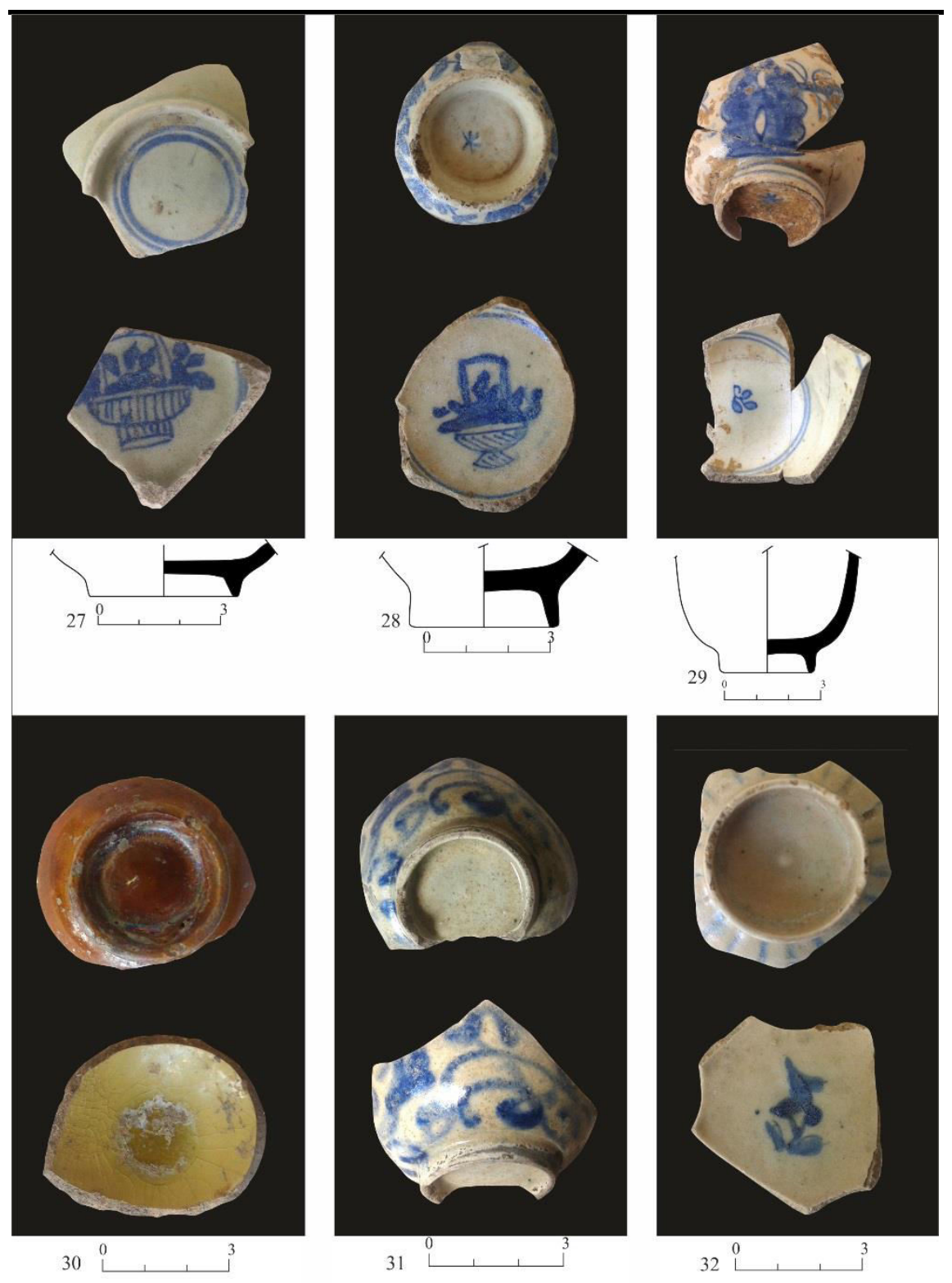

Tablo IV: Kütahya seramikleri (18. yüzyıl)

386 | Celal Bayar Üniversitesi Sosyal Bilimler Dergisi - Cilt: 17, Sayı: 3, Eylül 2019 